\title{
CHRONOTYPE AND WORK ACCIDENTS IN THE NURSING TEAM OF A SURGICAL CLINIC
}

\author{
Rosângela Marion da Silva1, Regina Célia Gollner Zeitoune², Carmem Lúcia Colomé Beck³, Sônia Beatriz \\ Coccaro de Souza $a^{4}$ Elisandra Santos ${ }^{5}$
}

${ }^{1}$ Ph.D. in Sciences (DINTER) from the Universidade Federal de São Paulo, Universidade Federal de Santa Maria (UFSM) and the Escola
de Enfermagem Anna Nery (EEAN) of the Universidade Federal do Rio de Janeiro (UFRJ). Assistant Professor of the Department
of Nursing, UFSM. Santa Maria, State of Rio Grande do Sul, Brazil. E-mail: cucasma@terra.com.br
2 Ph.D. in Nursing. Full Professor of the Department of Public Health Nursing, EEAN/UFRJ. Rio de Janeiro, State of Rio de
Janeiro, Brazil. E-mail: regina.zeitoune@gmail.com
${ }^{3}$ Ph.D. in Philosophy of Nursing. Associate Professor of the Department of Nursing, UFSM. Santa Maria, State of Rio Grande
do Sul, Brazil. E-mail: carmembeck@gmail.com
${ }^{4}$ Ph.D. in Psychiatry. Adjunct Professor of the School of Nursing of the Federal University of Río Grande do Sul. Porto Alegre,
State of Rio Grande do Sul, Brazil. E-mail: ssouza@hcpa.ufrgs.br
${ }^{5}$ M.A in Production Engineering. Statistics. Santa Maria, State of Rio Grande do Sul, Brazil. E-mail: elisandrafaccim@gmail.com

ABSTRACT: This quantitative, transversal study aimed to analyze the association between chronotype and the occurrence of work accidents in nursing workers. A total of 47 individuals participated from the Surgical Clinic of a teaching hospital in the Brazilian state of Río Grande do Sul. Data collection took place in July-August 2012, using a questionnaire for socio-demographic/occupational characterization and Horne and Östberg's Morningness-eveningness questionnaire. The data were analyzed using the SPSS software, version 15.0. The results evidenced the prevalence of individuals with the morning chronotype. The majority had been involved in work accidents, with the greatest occurrence being related to the concordance between the chronotype and the work shift. A significant association was observed between work accidents and shift, and between chronotype and shift. The data reinforce the need to raise workers' awareness regarding the importance of identifying the prototype so as to contribute to the quality of life and safety at work. DESCRIPTORS: Nursing. Work accidents. Shift work. Worker's health. Circadian rhythm.

\section{CRONÓTIPO E ACIDENTE DE TRABALHO NA EQUIPE DE ENFERMAGEM DE UMA CLÍNICA CIRÚRGICA}

\begin{abstract}
RESUMO: Estudo quantitativo, transversal, que objetivou analisar a associação entre cronótipo e a ocorrência de acidente de trabalho em trabalhadores de enfermagem. Participaram 47 indivíduos de Clínica Cirúrgica de um hospital universitário do Rio Grande do Sul. A coleta de dados ocorreu de julho a agosto de 2012, utilizando-se um questionário para caracterização sociodemográfica/laboral e o Questionário de Matutinidade/Vespertinidade de Horne e Östberg's Morningness-eveningness questionnaire. Os dados foram analisados com o auxílio do software SPSS-versão 15.0. Os resultados evidenciaram a prevalência de indivíduos com cronotipo matutino. A maioria se envolveu com acidente de trabalho, sendo a maior ocorrência relacionada à concordância entre o cronótipo e o turno de trabalho. Constatou-se associação significativa entre acidente de trabalho e turno e entre o cronótipo e turno. Os dados reforçam a necessidade de sensibilizar os trabalhadores para a importância de identificação do cronotipo de forma a contribuir para a qualidade de vida e segurança no trabalho.
\end{abstract}

DESCRITORES: Enfermagem. Acidentes de trabalho. Trabalho em turnos. Saúde do trabalhador. Ritmo circadiano.

\section{CRONOTIPO Y ACCIDENTE DE TRABAJO EN TRABAJADORES DE ENFERMERÍA DE CLÍNICA QUIRÚRGICA}

\begin{abstract}
RESUMEN: Estudio cuantitativo transversal, con el objetivo analizar la asociación entre cronotipo y la ocurrencia de accidente de trabajo en trabajadores de enfermería. Participaron 47 individuos de clínica quirúrgica de un hospital universitario, ubicado en Rio Grande do Sul, Brasil. La recolecta de datos ocurrió desde julio hasta agosto de 2012, utilizándose un cuestionario para caracterización sociodemográfica/laboral y el Cuestionario de Matutinidad/Vespertinidad de Horne y Östberg. Los datos fueron analizados con el auxilio del software SPSS-versión 15.0. Los resultados evidenciaron la prevalencia de individuos con cronotipo matutino. La mayoría estuvo involucrada con accidentes de trabajo, siendo que la mayor ocurrencia estuvo relacionada a la concordancia del trabajador al cronotipo y turno de trabajo. Se constató la asociación significativa entre accidente de trabajo y turno de trabajo y entre el cronotipo y el turno de trabajo. Los datos llaman la atención para la necesidad de sensibilizar los trabajadores para la importancia de la identificación del cronotipo como forma a contribuir para la calidad de vida y seguridad en el trabajo.
\end{abstract}

DESCRIPTORES: Enfermería. Accidentes de trabajo. Trabajo por turnos. Salud laboral. Ritmo circadiano. 


\section{INTRODUCTION}

Changes in the world of work, characterized in recent years by globalization and the introduction of new technologies, have had repercussions on workers' health, the object of interest of researchers in the area of health. These changes have established new relationships between workers and their work contexts, which have required scientific-technological knowledge, dynamicity in the work processes, the capacity to confront adverse situations, and a certain adaptability to the work conditions in order to meet the population's demands.

The concern with the worker and the environment in which she functions was highlighted in Brazil in 1990, with Law ${ }^{\circ}$. 8080/90, which concerns conditions for the promotion, protection and recovery of health and which has - among its objectives and characteristics - the undertaking of actions for workers' health, including, among others, the control of risks and potential threats to health existent in the work process. ${ }^{1}$ In 2012, the Brazilian National Worker's Health Policy was instituted, which, in the chapter on principles and directives, considers that in order to implement such a policy, it is necessary to consider the articulation between the individual and collective actions of health promotion, harm prevention and surveillance of work environments, processes and activities, with intervention regarding the factors which determine workers' health. ${ }^{2}$

These factors may be influenced by the organization of the work or by the individual worker's tendencies, with emphasis placed on Chronobiology. The science studies the temporal organization of biological, physiological and/or psychological phenomena, and makes it possible to understand that the organism differs physiologically at each point of the day, with different ability to react to environmental stimuli, whether these are physical, chemical, biological or social. ${ }^{3}$ Chronobiology includes the study of biological rhythms, characterized by the recurrence of biochemical, physiological and behavioral events at regular intervals, which are controlled by external synchronizers such as light and food, among others, but which also persist without environmental pointers, which characterizes them as endogenously generated rhythms.

The external stimuli, such as the lightdarkness cycle, serve to synchronize the internal rhythms with the environment, as the organism reacts differently during the day and the night, the fact of being asleep or awake having little importance. With the insertion of the study of Chronobiology, some questions relating to the process of individuals' adjustment to a new temporal situation imposed by the work schedule have been clarified. ${ }^{3}$

As a result, one of Chronobiology's objectives is to apply the knowledge of these rhythms to the study of human performance, so as to serve as guidance for allocating the worker in accordance with the time at which this is best disposed to undertake the activity. It is in this aspect that the study of the chronotype or chronobiological profile is inserted, considered a factor which can influence the health of workers who undertake their activities in shifts.

In accordance with individual differences, the individuals are classified as morning chronotype - those who prefer to go to bed and wake up early, with a good level of alertness and physical/ mental performance for work activities in the morning, as those with the evening chronotype - who prefer to go to bed and wake up late, and who have good performance for work activities in the afternoon and evening, or as indifferent individuals who have greater flexibility, choosing intermediate timetables, in accordance with the needs imposed by their routines. ${ }^{4}$

Based on these considerations, it can be seen that, in preparing work schedules, one should take into account the workers' individual tendencies, which will repercuss positively on safety at work, the control of risks, and on the reduction of threats to the workers' health, such as work accidents. A work accident is an event which occurs in undertaking work and which entails harm to health, either potential or immediate, provoking bodily injury or functional disturbance which causes loss or reduction of capacity to work, either permanent or temporary. ${ }^{5}$

In the specific ambit of work undertaken in hospitals, the nursing professionals experience an intense working rhythm, which, associated with the division of the work into shifts, subjects them to the process of adaptation of the organism, and makes them vulnerable to the occurrence of work accidents, which can, among other issues, involve sharps and/or the contamination of mucosa. In order to avoid these, as well as to promote the worker's health, it is necessary to raise their awareness regarding the need to adopt safety measures (currently termed standard precautions) regarding exposure to blood and biological fluids, and the use of personal protective equipment. ${ }^{6}$ 
As a result, in relation to the fact that the work organization can exercise influence on the worker's health, emphasis is placed on the study of the chronotype, which can be used as a reference for identifying in which period the individual is most fit to undertake her activities, which can contribute to the worker's well-being, and to healthy aging, providing quality of life and security for those whom she assists.

In relation to this, studies have sought to identify the chronotype of the nursing workers, ${ }^{7}$ and to associate it with quality of life, ${ }^{8}$ with stress, ${ }^{3}$ and with occupational stress. ${ }^{9}$ For this study, it was sought to respond to the following guiding question: is there an association between the chronotype and the occurrence of work accidents among nursing workers?

Thus, based on the need to broaden the discussion regarding the chronotype and the implications for the health of nursing workers, with the aim of bringing support for the promotion of the worker's health and the construction of knowledge in nursing, the objective of this study was established as analyzing the association between chronotype and the occurrence of work accidents. It is based on the assumption that individuals with concordance between chronotype and work shift are less involved in work accidents when compared to those with discordance.

\section{METHOD}

This quantitative transversal study was undertaken in a teaching hospital, an organ belonging to a federal institution located in the State of Río Grande do Sul. The above-mentioned institution has 291 bed spaces for inpatient treatment; the unit chosen for the study was the Surgical Clinic, which has capacity to attend 46 patients, and which has 49 nursing workers (11 nurses, 25 nursing technicians and 13 auxiliary nurses). The choice was made due to the fact that this was the largest inpatient unit in the institution.

The inclusion criteria for participants in the study were: to have worked in nursing for at least one year, to work in the morning (7-13 hrs), afternoon (13-19 hrs) or night shift (19 hrs to $7 \mathrm{hrs}$ on the following day) providing direct care to the patients. Those who were on leave or away from work for any reason during the data collection period were excluded. With the inclusion and exclusion criteria, 47 participants remained, of whom nine were nurses, 25 were nursing technicians, and 13 were auxiliary nurses.

Following the approval of the project by the Research Ethics Committee of the Federal University of São Paulo (Certificate of Presentation for Ethical Consideration n. 02505512.4.0000.5505), the subjects were individually approached in the work environment, the study objectives were explained to them, and they were invited to participate in the study, as stipulated by the ethical precepts for research involving human beings. ${ }^{10}$ The participants received two copies of the Terms of Free and Informed Consent, and were advised to read and sign them if they agreed with the terms explained, one copy remaining with the researcher and the other with the interviewee. There were no refusals.

Data collection took place in July and August 2012, in the place of work, by shift, without being previously arranged, and through a self-applied questionnaire handed over individually. The socio-demographic and occupational data were evaluated, and the Morningness-Eveningness Questionnaire (MEQ) was used, which determines the chronotype based on preferences for allocating the periods of the activities and rest.

The MEQ is an instrument created by Horne and Östeberg, ${ }^{4}$ and was translated and validated for the Brazilian context. ${ }^{11}$ The questionnaire is made up of 19 questions, with multiple-choice answers relating to the main activities undertaken by the individual throughout the day, with the final score being obtained by the arithmetical sum for each question, reflecting the preferred time for undertaking routine activities. The scores vary from 16 to 86 points and make it possible to classify the individual in accordance with his or her chronotype: from 16 to 33 points is the evening chronotype; 34 to 44 points is moderately evening; 45 to 65 points is indifferent; 66 to 76 points is moderately morning; and 77 to 86 points is morning. The higher the score, the higher is the tendency to morningness, and the lower the score, the greater the tendency to eveningness. Intermediate scores (indifferent chronotype) indicate that the worker does not present a tendency for a specified work shift, and that she can adapt with a certain ease to any shift. For this study, it was decided to classify individuals as morning, evening and indifferent, not considering the sub-classifications.

It was determined that the person with a morning chronotype or indifferent chronotype who worked in the morning shift presented concordance, as did the person with the evening 
chronotype or indifferent chronotype who worked on the afternoon or night shift. The discordances are those situations in which morning individuals work in the afternoon or night shift, and the evening individuals work on the morning shift.

Following independent double-keying of the data in an Excel spreadsheet, for verification of errors and inconsistencies, the data were analyzed statistically using the Predictive Analytics Software of SPSS INc., Chicago, USA, version 15 for Windows. The qualitative variables were described through absolute and relative frequen$c y$, while when the quantitative variables were analyzed, the Kolmogorov-Smirnov test was undertaken to ascertain the adherence of the data to normal distribution.

The quantitative variables which followed normal distribution were presented by mean and standard deviation, and those which did not have a normal pattern of distribution were described through medians and interquartile interval. Associations were ascertained through the Chi-squared test, with later calculation of the adjusted residues. All the analyses were undertaken considering a level of significance of $5 \%(a \leq 0.05)$. The MEQ's internal consistency was evaluated using the Cronbach alpha coefficient $(a=0.86)$.

\section{RESULTS}

A total of 47 nursing workers participated in the study, of whom $53.19 \%(n=25)$ were nursing technicians, with a mean age of 36.08 years old $( \pm 8.33), 27.66 \%(n=13)$ were auxiliary nurses, with a mean age of 47.7 years old $( \pm 6)$, and $19.15 \%(n=9)$ were nurses, with a mean age of 41.33 years old $( \pm 6.91)$. The time of work for the nurses was 8 years (2.5-12.5); for the auxiliary nurses, it was 19 years (17.5 - 26.0); and for the nursing technicians, it was 5 years $(2.7-9.0)(\mathrm{p}<0.001)$. The group's mean age was 40.32 years $( \pm 8.92)$ and the mean time of work in the Surgical Clinic was 19 years $(17.5-26.0)$.

In relation to the socio-demographic data, it was ascertained that $89.4 \%(n=42)$ are female, $66.0 \%(n=31)$ are married, and $68.1 \%(n=32)$ have children. It was identified that $57.4 \%(n=27)$ did not undertake physical activity and that $61.7 \%(n=29)$ were not using medication. There was significant association between the professional category and the use of medication $(\mathrm{p}=0.025)$.
Regarding occupational data, it was identified that $48.9 \%(n=23)$ worked on the night shift, $76.6 \%(n=36)$ chose the shifts they wanted, that $83.0 \%(n=39)$ did not have another job ${ }^{*}$ and that 93.6\% $(n=44)$ were satisfied with the job.

Among the professional categories, it was observed that $50.0 \%(n=15)$ of the nursing technicians had already experienced accidents, followed by $33.4 \% \quad(n=10)$ of the auxiliary nurses, and $16.6 \%(n=5)$ of the nurses $(p=0.499)$. Among those involved with work accidents $(n=30)$, it was observed that $63.3 \%(n=19)$ were allocated to the night shift; $13.3 \%(n=4)$, to the morning shift; and $23.4 \%(n=7)$, to the afternoon shift $(\mathrm{p}=0.022)$.

The frequency of the scores of the Morningness-Eveningness Questionnaire evidenced variation from 31 to 79 points $(55.7 \% \pm 12.69)$. In Table 1 , one can observe that $46.8 \%(n=22)$ have the morning chronotype. Among the auxiliary nurses, $53.8 \%(n=7)$ have the indifferent chronotype; $48.0 \%$ $(n=12)$ of the nursing technicians and $66.7 \%(n=6)$ of the nurses have the morning chronotype. In relation to the socio-demographic variables, professional category and chronotype, there was no significant association $(p=0.341)$.

Table 1 - Chronotype of the nursing workers of the Surgical Clinic, by professional category. Santa Maria, State of Río Grande do Sul-RS, $2013(n=47)$

\begin{tabular}{lcccc}
\hline Professional & \multicolumn{3}{c}{ Chronotype } & \multirow{2}{*}{ p $^{*}$} \\
\cline { 2 - 4 } category & Indifferent & Morning & Evening & \\
\hline Auxiliary & $7(53,8 \%)$ & $4(30,8 \%)$ & $2(15,4 \%)$ & \\
Nurse & & & & 0,341 \\
Nursing & $6(24,0 \%)$ & $12(48,0 \%)$ & $7(28,0 \%)$ & \\
Technician & $3(33,3 \%)$ & $6(66,7 \%)$ & $0(0,0 \%)$ & \\
Nurse & $16(34,0 \%)$ & $22(46,8 \%)$ & $9(19,2 \%)$ & \\
Total & & & & \\
\hline
\end{tabular}

${ }^{*}$ Chi-squared test.

According to table 2, the workers who worked on the morning shift presented concordance in the order of $100 \%$ (morning chronotype). Among those who worked on the afternoon shift, a discordance was observed between the chronotype and the work shift, as it was observed that $30.8 \%(n=4)$ of the individuals had the morning chronotype, that is to say, they were persons with a tendency to work on the morning shift and had

\footnotetext{
* Due to low salaries, it is common for Brazilian nursing staff to work two shifts a day, sometimes in different institutions. Translator's note.
} 
been allocated to the afternoon shift. Among the individuals who worked at night, discordance was also observed between the chronotype in the work shift, as it was observed that $30.4 \%(n=7)$ of the workers had the morning tendency. There was a significant association between the chronotype and the work shift $(\mathrm{p}=0.001)$.

Table 2 - Distribution of the chronotype of nursing workers of the Surgical Clinic by work shift. Santa Maria-RS, $2013(n=47)$

\begin{tabular}{lcccc}
\hline \multirow{2}{*}{ Work Shift } & \multicolumn{3}{c}{ Chronotype } & \multirow{2}{*}{ p $^{*}$} \\
\cline { 2 - 4 } & Indifferent & Morning & Evening & \\
\hline Morning & $0(0.0 \%)$ & $11(100 \%)$ & $0(0.0 \%)$ & \\
Afternoon & $8(61.5 \%)$ & $4(30.8 \%)$ & $1(7.7 \%)$ & 0.001 \\
Night & $8(34.8 \%)$ & $7(30.4 \%)$ & $8(34.8 \%)$ & \\
Total & $16(34.0 \%)$ & $22(46.8 \%)$ & $9(19.1 \%)$ & \\
\hline
\end{tabular}

* Chi-squared test.

It is observed, in table 3, that there was no association between individuals with concordance or discordance between the work shift and chronotype, and involvement or not with work accidents. When analysis was undertaken in relation to the individuals with concordance or discordance between the workshift and chronotype, it was noted that $56.7 \%(n=17)$ of the workers with concordance had suffered a work accident. Among the work shifts, the night shift presented the percentage of $63.3 \%(n=19)$ of work accidents $(p=0.022)$.

Table 3 - Distribution of nursing workers of the Surgical Clinic with concordance and discordance, by work accident. Santa Maria-RS, 2013 (n=47)

\begin{tabular}{llll}
\hline Work accident & Concordance & Discordance & $\mathbf{p}^{*}$ \\
\hline Yes & $17(56.7 \%)$ & $13(43.3 \%)$ & 0.411 \\
No & $11(64.7 \%)$ & $6(35.2 \%)$ & \\
\hline
\end{tabular}

${ }^{*}$ Chi-squared test.

\section{DISCUSSION}

The predominance of women in this study is a reality also found in other studies with nursing workers. $^{8-9}$

These are workers with a mean time of work in the unit studied of 19 years. These data suggest that the workers in this study possess a relative personal and professional experience, factors which may be favorable to the workers' sensitization to care for their health in the work environment. It is observed that the auxiliary nurses were the workers who had worked in the unit in question for a period of years which was greater in comparison with the nursing technicians $(\mathrm{p}<0.001)$.

In relation to the participants' age, it was observed that the individuals with greater mean age (auxiliary nurses - mean of 47.7 years old) presented the indifferent chronotype, which may suggest that they are people who have been adapting over their lives. ${ }^{9}$ This result is divergent from another study which considers that, as age progresses, the individuals have the disposition to bring forward the phase of their biological rhythms, with a tendency to become more morning, a tendency which is contrary to that found in puberty. ${ }^{12}$

It was observed that $57.4 \%$ did not practice physical activity, a result also found in a study with nursing technicians. ${ }^{13}$ In this regard, authors mentioned that the practicing of physical exercise contributes to the active search for health, being an integral part of caring for oneself and promoting health, ${ }^{14}$ as sedentarism is a factor which compromises peoples' health and quality of life.

It was also observed that $61.7 \%$ of the workers did not use any type of medication. However, among those who make use of medication, a significant association was observed with the position of auxiliary nurse $(p=0.025)$. This data may be associated with these individuals' age, as the aging process is accompanied by multiple chronic-degenerative health problems requiring specific treatment, and which often entail the use of drugs. ${ }^{15}$

Regarding the occurrence of work accidents, the percentage of $63.8 \%$ was evidenced, a significant association being found among those who had accidents and the night shift $(\mathrm{p}=0.022)$. Work accidents and occupational illnesses are related to the worker's exposure to the type of work exercised, to the use of protective measures and safety, ${ }^{16}$ and to the time of work, which is directly related to the worker's exposure to the occupational risks present in the work context.

The majority of the workers do not have another job (83\%) and were satisfied with the work $(93.6 \%)$, factors which may impact favorably on the worker's health.

In relation to the chronotype, it was observed that in the group, the morning type predominated (46.8\%), a result which is similar to some studies undertaken with these workers, ${ }^{7,17}$ and which diverges from others, which found indifferent chronotype. . $^{3,8-9,18-19}$ 
To classify an individual as indifferent in relation to his chronotype means to say that he adapts, with a certain ease, to changes in the timetable, and that he can wake up both earlier and later, being able to undertake work activities in both periods, and at a satisfactory level of alertness. Thus, undertaking activities outside the period referent to the chronotype may entail difficulties in adapting for the organism, as there are no tasks which are exclusively mental or physical, or which make use only of the memory, visual perception, muscular strength or attention. ${ }^{19}$

Identifying the chronotype of nursing workers is an important differential in the health organizations, as it enables the manager to allocate the worker according to his or her individual performance and level of alertness, which can contribute to safety at work, quality of life, and well-being.

When chronotype and work shift were associated, a significant statistical difference was observed $(p=0.001)$. Thus, the workers of the morning shift were more associated with the morning chronotype; those of the afternoon shift, with the indifferent chronotype; and the workers of the night shift were more associated with the evening chronotype.

The discordance between chronotype and the shift in which the worker exercises her activities can result in imbalance in her biological rhythm, as there is the requirement for adaptation of the organism, which can lead to exhaustion, with organic reflections and disturbances in the social and family dynamic, ${ }^{20}$ situations which can present as illnesses and withdrawal from work. ${ }^{7}$

When the occurrence of work accidents is associated with presenting concordance or discordance, it was identified that there was a predominance of concordance among the workers who had suffered work accidents. In spite of no significant statistical association being found $(p=0.411)$, these data need to be considered in the context of the health of the workers, as disharmony between the chronotype and work shift can entail repercussions for the worker's health.

The discordance between the chronotype in the work shift supposes a disassociation between the biological, psychological and social rhythms of the workers who work in shifts, which may be related to misalignment between their circadian system and the internal and external synchronizers, often causing disturbances in family and social life and in health, in the short and long-terms. ${ }^{7}$
Thus, when a night shift worker with a morning chronotype is identified, it is nearly impossible to adopt efficient strategies, because the genetic constitution of the biological rhythm is organized temporally by internal structures. If the possibility exists for there to be some psychological interference, such as a motivation for undertaking work on the night shift which will repercuss favorably on the worker's life, this problem could, to a degree, be circumvented. ${ }^{21}$

In this way, if the nursing workers' shift were compatible with the tendency of their biological clocks, situations such as absenteeism, problems with interpersonal relationships, and organization of the work could be minimized. ${ }^{7}$ In order to produce health, it is necessary to take into account the care for oneself, besides the care for the other, with co-responsibilization on the part of the institution and the worker for the production of the health of the worker, ${ }^{22}$ who is often negligent in relation to situations which she recognizes as being unfavorable to her health.

In the context of the work undertaken in shifts, the need is urgent to evaluate the relationship of the chronotype with the work shift, with the intention of preventing occupational health issues and risks, as well as to promote the workers' health and quality of life. In this process, one must consider age and sex, as well as the work conditions offered.

\section{CONCLUSION}

This study's results did not confirm an association between the chronotype and the occurrence of work accidents in the nursing workers of the Surgical Clinic. However, although it has been observed that the individuals with discordance have suffered work accidents, this result does not demonstrate that the work accident may have been influenced by the chronotype. Further studies, with larger samples, associating the chronotype with different aspects of the work context which may repercuss on the nursing workers' health, are necessary.

On the other hand, the results evidenced a significant association between chronotype and work shift, suggesting that the workers who work in the morning presented concordance between their chronotype and work shift. This data indicates that, for the group of people with discordance, the work shift exercises an influence on the individual tendencies, which constitutes a possible determinant factor for the occurrence 
of harm to the worker's health, but which need further investigation regarding the influence of the work shift on the worker's life.

The identification of the important number of occurrences of work accidents, the greatest frequency happening during the night shift, must be a reason for concern for the institute researched. Although it is supposed that nursing is one of the professions of the health area which is most exposed to the occurrence of work accidents, it is necessary for the managers to take into account some characteristics of the hospital organization or environment which may contribute to the occurrence of work accidents in nursing, such as the system of work shifts, and the overload which results from the insufficient number of human resources. Thus, it is essential to undertake scheduled actions of health education, ideally in conjunction with the Occupational Health Service, in an ongoing and systematized way, in order to sensitize the workers, raise their awareness, and guide the workers in relation to the health issues to which they are exposed in the work environment, which could contribute to the prevention of these occurrences.

It is necessary for the centers which train the future professionals to sensitize them regarding the factors inherent to the process of nursing work which can influence the worker's health, making possible their engagement in issues directed at maintaining their health as workers.

One must also consider that the routine of hospital work involves multiple factors which can contribute to the occurrence of work accidents, such as work overload, physical and mental tiredness and the undertaking of unsafe practices, among others which influence the workers' health and which were not investigated, which constitutes a limitation of this study. Furthermore, the fact that the interviewees were not questioned regarding the type of medication or the nature of the accidents also constitutes a limitation, along with the limitations intrinsic to transversal studies, in which it is not possible to make conclusions regarding causal relationships.

Therefore, it is necessary to raise the awareness of managers regarding the importance of identifying the workers' chronotype, so as to contribute to quality of life and safety at work.

\section{ACKNOWLEDGEMENTS}

The authors express their gratitude for the financial assistance extended by the National
Counsel of Scientific and Technological Development's Universal Announcement n. 14/2011 for the undertaking of this study.

\section{REFERENCES}

1. Brasil. Lei n. 8.080, de 19 de setembro de 1990 . Dispõe sobre as condições para promoção, proteção e recuperação da saúde, a organização e funcionamento dos serviços correspondentes e dá outras providências [online]. Brasília; 1990 [acesso 2013 Mar 15]. Disponível em: http://www010. dataprev.gov.br/sislex/paginas/42/1990/8080.htm

2. Ministério da Saúde (BR). Portaria n. 1.823 de 23 de agosto de 2012. Institui a Política Nacional de Saúde do Trabalhador e da trabalhadora [online]. Brasília. 2012 [acesso 2013 Abr 14]. Disponível em: http:// bvsms.saude.gov.br/bvs/saudelegis/gm/2012/ prt1823_23_08_2012.html

3. Ferreira LRC, De Martino MMF. Stress no cotidiano da equipe de enfermagem e sua correlação com o cronótipo. Estud Psicol. 2009 Jan-Mar; 26(1):65-72.

4. Horne JA, Ostberg O. A self-assesment questionnaire to determine morningness-eveningness in human circadian rhythms. Int J Chronobiol. 1976;4(2):97-110.

5. Ministério da Saúde (BR). Notificação de acidentes de trabalho fatais, graves e com crianças e adolescentes [online]. Brasília (DF): Ministério da Saúde; 2006. [acesso 2014 Jun 14]. Disponível em: http:/ / bvsms. saude.gov.br/bvs/publicacoes/06_0442_M.pdf

6. Valim MD, Marziale MHP. Avaliação da exposição ocupacional a material biológico em serviços de saúde. Texto Contexto Enferm. 2011; 20(Esp):138-46.

7. Xavier KGS, Vaghetti HH. Aspectos cronobiológicos do sono de enfermeiras de um hospital universitário. Rev Bras Enferm. 2012 Jan-Fev; 65(1):135-40.

8. Souza SBC, Tavares JP, Macedo ABT, Moreira PW, Lautert L. Influência do turno de trabalho e cronotipo na qualidade de vida dos trabalhadores de enfermagem. Rev Gaúcha Enferm. 2012 Dez; 33(4):79-85.

9. Dalarosa MG, Lautert L. Acidente com material biológico no trabalhador de enfermagem em um hospital de ensino: estudo caso-controle. Rev Gaúcha Enferm. 2009 Mar; 30(1):19-26.

10. Ministério da Saúde (BR). Resolução n. 466, de 12 de dezembro de 2012. Dispõe sobre as diretrizes e normas regulamentadoras de pesquisas envolvendo seres humanos. Brasília (DF): Conselho Nacional de Saúde; 2012

11. Benedito-Silva AA, Menna-Barreto L, Tenreiro S. Self-assessment questionnaire for the determination of morningness-eveningness types in Brazil. Prog Clin Biol Res. 1990; 314B:89-98.

12. Monk TH, Kupfer DJ. Which aspects of morningnesseveningness change with age? J Biol Rhythms. 2007 Jun; 22(3):278-80. 
13. Coelho ACVD, Ramos IC, Almeida SS, Braga VAB, Coelho PBB. Técnico de enfermagem e o cuidado da sua saúde. Cienc Cuid Saude. 2010 Jul-Set; 9(3):487-93.

14. Sebold LF, Radünz V, Carraro TE. Promoção da saúde e sobrepeso em acadêmicos de Enfermagem. Esc Anna Nery Rev Enferm. 2011 Jul-Set; 15(3):536-41.

15. Silva CSO, Pereira MI, Yoshitome AY,Neto JFR,Barbosa DA. Avaliação do uso de medicamentos pelo idoso. Esc Anna Nery Rev Enferm. 2010 OutDez; 14(4):811-8.

16. Silva MKD, Zeitoune RCG. Riscos ocupacionais na perspectiva da enfermagem. Esc Anna Nery Rev Enferm. 2009 Abr-Jun; 13(2):279-86.

17. Witt SC, Pereira KF, Bianchi FJ, Bianchi LRO. Identificação de cronotipos de técnicos e enfermeiros dos hospitais Imaculada Conceição de Realeza e Capanema-PR. Rev Biol Saúde Unisep. 2009; 3(2):43-53

18. De Martino MMF, Abreu ACB, Barbosa MFS, Teixeira JEM. The relationship between shift work and sleep patterns in nurses. Ciênc Saúde Coletiva. 2013 Mar; 18(3):763-8.

19. Alves PC, Neves VF, Dela Coleta MF, Oliveira AF. Avaliação do bem-estar no trabalho entre profissionais de enfermagem de um hospital universitário. Rev Latino-Am Enfermagem. 2012 Jul-Ago; 20(4):701-9.

20. Araújo AJ. Trabalho em turnos e noturno e cronobiologia. In: Jasen JM, organizador. Medicina da noite: da cronobiologia prática clinica. Rio de Janeiro (RJ): FIOCRUZ; 2007. p. 299-324.

21. De Martino MMF, Basto LM. Qualidade do sono, cronótipos e estado emocional: o caso de enfermeiros portugueses que trabalham por turnos. Pensar em enfermagem. 2009; 13(1):49-60.

22. Azambuja EP, Pires DEP, Vaz MRC, Marziale MH. É possível produzir saúde no trabalho da enfermagem? Texto Contexto Enferm. 2010 OutDez; 19(4):658-66. 